\title{
Assessment of Groundwater Quality in Close Proximity to Septic Tanks and Potential Impact on Health
}

\author{
Chinwendu Emeka, Bright Nweke, Chimaob K. Ihunwo, and Samuel Nta
}

\section{ABSTRACT}

\begin{abstract}
A field study was conducted to assess groundwater samples collected in close proximity to septic tanks and its potential impact on health. pH, Total Alkalinity, Total Hardness. TDS, BOD, Turbidity, EC, Magnesium, Phosphate, Sulphate, Chloride, Nitrate, $\mathrm{Cu}, \mathrm{Fe}, \mathrm{Pb}$ and $\mathrm{Cd}$ were determined using standard methods. The human health risk assessment was performed by determining the hazard quotient of physicochemical and heavy metals through human oral consumption. The results indicate that the hazard quotient for $\mathrm{pH}$, Total Alkalinity, Total Hardness, TDS, BOD, Turbidity, EC, Magnesium, Phosphate, Sulphate, Chloride, Nitrate, $\mathrm{Cu}, \mathrm{Fe}, \mathrm{Pb}$ and $\mathrm{Cd}$ were less than 1 while Temperature (1.1, 1.1 and 1,1), Dissolved Oxygen [CE1(3.3), CE2(3.8) and CE3(3.7)] and Calcium [CE1 (0.0), CE2 (2.6), and CE3 (1.2)] except for CE1 were greater than 1 . This indicates that the borehole water poses risk for human consumption. Regulatory agencies should be proactive in monitoring borehole water quality, agencies in charge of approving building plan should ensure a safe distance between borehole water and septic tank is maintained and enforced.
\end{abstract}

Keywords: Contamination, Hazard quotient, Septic tank.
Published Online: January 9, 2021

ISSN: $2684-446 \mathrm{X}$

DOI :10.24018/ejgeo.2021.2.1.104

C. Emeka *

Rivers State University, Port Harcourt, Nigeria.

(email: chinwendu.emeka1@ust.edu.ng) B. Nweke

Rivers State University, Port Harcourt, Nigeria.

(e-mail: brightnweke065@gmail.com)

C. K. Ihunwo

Rivers State University, Port Harcourt, Nigeria.

(e-mail: chimaobi.ihunwo@ust.edu.ng)

S. A. Nta

Aqua Ibom State University, Ikot Akpaden, Nigeria.

(e-mail: samuelnta@aksu.edu.ng)

*Corresponding Author

\section{INTRODUCTION}

Groundwater is a main source of fresh water that are normally used for domestic, industrial and agriculture (irrigation) purposes. Groundwater in general is more palatable paralleled to surface water because of it selfcleansing capacity and simplicity of treatment. The fresh water typically used for different purposes is vulnerable to contamination due to anthropogenic activities in the area. Although there are natural factors such as nature of bed rock geology, depth from surface soil, vegetation, climatic variation, permeability of sediments, and topography, while anthropogenic factors are nature of human activities such urbanization, industrialization, waste management disposal, amongst other that influences groundwater. One of the main causes of groundwater pollution in urban areas is contamination by septic tanks because of its location.

The present of bacteria and viruses in domestic sewage, pollution of ground water by septic tank systems may result in outbreaks of disease. Pollution of ground water by septic tanks is more likely to occur where depth to water is shallow, septic tanks are closely spaced, and aquifer materials and soils have high permeability than where these factors are absent; sand and gravel aquifers are among the aquifers most susceptible to pollution [1], [3].

Readily available and safe water is key for public health. Safe water supply, sanitation and water resources management can boost countries' economic growth and greatly contribute to poverty reduction [14]. Improper management of water and sanitation services expose individuals to preventable health risk.

Human health risk assessment estimates the nature and probability of adverse health effects in humans who may be exposed to chemicals in contaminated environmental media, now or in the future. There are four basic steps in human health risk assessment which includes hazard identification, dose-response assessment, exposure assessment and risk characterization [4]. In this study, hazard quotient was used to assess the potential health risk of groundwater users in close proximity to septic tanks.

\section{MATERIALS AND METHODS}

\section{A. Study Area}

The study was carried out at Obio/Akpor (CE 1), Etche (CE 2) and Omuma (CE 3) local government areas, River state, Nigeria. The local government are situated at $4.87^{\circ} \mathrm{N}$ latitude and $6.92^{\circ} \mathrm{E}$ longitude, $5.04^{\circ} \mathrm{N}$ latitude and $7.05^{\circ} \mathrm{E}$, longitude, and $5.09^{\circ} \mathrm{N}$ latitude and $7.23^{\circ} \mathrm{E}$ longitude respectively. The average annual temperature of the area is $26.4^{\circ} \mathrm{C}$ and rainfall average of about $2100 \mathrm{~mm}$.

\section{B. Sample Collection and Analysis}

Boreholes water samples were collected at 3 locations using $0.75 \mathrm{~L}$ capacity containers for laboratory analysis. The method adopted for analyzing the physicochemical and 
heavy metal parameters were in line with American Public Health Association [10].

\section{Risk Assessment on Human Health}

Hazard Quotient (HQ) is calculated using the following equation [5], [6].

$$
\text { Hazard Quotient }(H Q)=\frac{(\text { Exposure Concentration })}{(\text { Reference Concentration })}
$$

where

Exposure concentration is the concentration level of contaminant over the period of exposure; it is measured in $\mathrm{mg} / \mathrm{l}$ or $\mathrm{ppm}$.

Reference Concentration (RFC) is an estimate of a continuous ingestion unlikely to cause adverse health effects during a person's lifetime.

Hazard quotient less than or equal to 1 means that adverse effects are not likely to occur and thus can be considered to have negligible hazard. Hazard quotient greater than 1, indicates the potential for adverse effects are possible.

RFC are originated from [7], [11].

\section{RESULTS AND DISCUSSION}

Table 1 shows the WHO and NSDWQ maximum acceptable standards for drinking water quality. Table 2 presents the physicochemical and heavy metals of borehole water at different sampling locations. Table 3 distances between borehole water and septic tank at different sampling locations. Table 4 shows the calculated hazard quotient of borehole for each of the sample location.

Borehole water at a distance of less than 7 meters from septic tank as shown in Table 3 has a pH of less than 5 in all sampling points which is acidic, this is in conformity with the findings of [2] water from such source has corrosion tendencies and could cause corrosion of distribution lines made with metals.

As shown in Table 4 Hazard Quotient of $\mathrm{pH}$ in the borehole water samples CE1, CE2, and CE3 were 0.5, 0.6 and 0.6 respectively, which is less than 1 , this show that $\mathrm{pH}$ poses no risk to human health. Temperature of all sampling locations has hazard quotient of 1.1, which is clear indication that it poses a risk to human health, Turbidity of CE1, CE2, and CE3 has hazard quotient of $0,0.3$ and 0.1 , which is below 1, making turbidity harmless to human health. Turbidity can harbor microorganism safeguarding them from disinfection and can entrap heavy metals and biocide but has no direct health impact [13]. Dissolved Oxygen hazard quotient was 3.3, 3.8, 3.7 for borehole water sampling CE1, CE2, and CE3 respectively, it reveals that DO poses a risk to human health due to the degree of pollution caused by organic substance. The hazard quotient of Total Dissolved Solids on all sampling locations were less than 1, showing it poses no risk to human health. BOD poses no long-term risk to human health [13]. The hazard quotients of BOD were less than 1 , which revealed that it poses no risk to human health. Hazard quotient of Chloride $(0,0$ and 0$)$, Sulphate $(0,0$ and 0$)$. Magnesium $(0,0.3$, and $0.8)$, Phosphate (0, 0 and 0$)$, Total Alkalinity (0, 0.1 and 0$)$, Total Hardness (0, 0.7 and 0.6$)$, Nitrate $(0,0$ and 0$), \mathrm{Pb}(0.1$,
0.1 and 0.1$), \mathrm{Cd}(0.3,0.3$ and 0.3$)$ and $\mathrm{Fe}(0,0$ and 0.1$)$ for CE 1, CE2 and CE3 respectively, which means that the physicochemical and heavy metal parameters cause no risk to human health.

TABLE 1: WHO \& NSDWQ PERMISSIBLE LIMIT

\begin{tabular}{ccc}
\hline Parameters & WHO, 2011 & NSDWQ, 2015 \\
\hline $\mathrm{pH}$ & $6.5-8.5$ & $6.5-8.5$ \\
Temperature & 25 & - \\
Total Alkalinity & 200 & - \\
Total Hardness & 300 & - \\
TDS & 500 & 500 \\
DO & 2 & 5 \\
BOD & 10 & - \\
Turbidity & 5 & 5 \\
EC & 1000 & 1000 \\
Magnesium & 30 & 20 \\
\hline Phosphate & 0.1 & - \\
Sulphate & 100 & 100 \\
Calcium & 75 & 75 \\
Chloride & 250 & 250 \\
Cu & 2 & 1 \\
Fe & 0.3 & - \\
Nitrate & 50 & 50 \\
Pb & 0.01 & 0.01 \\
Cd & 0.003 & 0.003 \\
\hline
\end{tabular}

TABLE 2: MEASURED PHYSICOCHEMICAL AND HEAVy METALS PROPERTIES OF BOREHOLE WATER AT DIFFERENT SITES

\begin{tabular}{cccc}
\multicolumn{2}{c}{ PROPERTIES OF BOREHOLE W ATER AT DIFFERENT SITES } \\
\hline Parameters & CE 1 & CE 2 & CE 3 \\
\hline pH & 4.1 & 4.8 & 4.7 \\
Temperature & 28.5 & 28.4 & 27.8 \\
Total Alkalinity & 4 & 18 & 7 \\
Total Hardness & 0 & 200 & 184 \\
TDS & 6.003 & 74.04 & 42.06 \\
DO & 6.5 & 7.5 & 7.4 \\
BOD & 4.9 & 4.06 & 5.02 \\
Turbidity & 0 & 1.63 & 0.5 \\
EC & 9 & 114 & 79 \\
Magnesium & 0 & 8 & 23 \\
Phosphate & 0.001 & 0.001 & 0.001 \\
Sulphate & 0.001 & 0.001 & 0.001 \\
Calcium & 0 & 192 & 90 \\
Chloride & 3.04 & 8.11 & 5.22 \\
Cu & 0.099 & 0.12 & 0.53 \\
Fe & 0.001 & 0.001 & 0.042 \\
Nitrate & 0.631 & 0.895 & 1.58 \\
Pb & 0.001 & 0.001 & 0.001 \\
Cd & 0.001 & 0.001 & 0.001 \\
\hline
\end{tabular}

TABle 3: Distance BetweEn Borehole Water AND SEPTIC TANK AT DIFFERENT SAMPLING SITES

\begin{tabular}{cc}
\hline Sampling Locations & Distance $(\mathrm{m})$ \\
\hline CE1 & 4.5 \\
CE2 & 6.4 \\
CE3 & 5.7 \\
\hline
\end{tabular}

TABLE 4: THE CALCULATED HAZARD QUOTIENT OF BOREHOLE WATER PHYSICOCHEMICAL AND HEAVy METALS FOR HEALTH RISK ASSESSMENT

\begin{tabular}{cccc}
\hline Parameters & CE 1 & CE2 & CE3 \\
\hline pH & 0.5 & 0.6 & 0.6 \\
Temperature & 1.1 & 1.1 & 1.1 \\
Total Alkalinity & 0 & 0.1 & 0 \\
Total Hardness & 0 & 0.7 & 0.6 \\
TDS & 0 & 0.1 & 0.1 \\
DO & 3.3 & 3.8 & 3.7 \\
BOD & 0.5 & 0.4 & 0.5 \\
Turbidity & 0 & 0.3 & 0.1 \\
EC & 0 & 0.1 & 0.1 \\
Magnesium & 0 & 0.3 & 0.8 \\
Phosphate & 0 & 0 & 0 \\
Sulphate & 0 & 0 & 0 \\
Calcium & 0 & 2.6 & 1.2 \\
Chloride & 0 & 0 & 0 \\
Cu & 0 & 0.1 & 0.3 \\
Fe & 0 & 0 & 0.1 \\
Nitrate & 0 & 0 & 0 \\
Pb & 0.1 & 0.1 & 0.1 \\
Cd & 0.3 & 0.3 & 0.3 \\
\hline
\end{tabular}


$\mathrm{Pb}$ is the most significant among other heavy metals because it is very toxic and harmful even in small concentration [12], it can also harbor in the body tissue causing harm to human, such as cancer, mental deficiencies, brain damage and even death [8] although, hazard quotient of $\mathrm{Pb}$ were 0.1 on all sampling locations CE1, CE2 and CE3 poses no risk to human being.

Cadmium in groundwater occurs when it come in contacts with soil contaminated with discharges from petroleum hydrocarbon through leaching, fertilizer, and paint [16]. High level of cadmium results to agonistic and antagonistic effects on hormone and enzymes posing health effect like cancer and kidney failure [9], [13].

Cadmium hazard quotients in all sampling locations were less than 1, making Cadmium a no risk physicochemical parameter in selected borehole water. Hazard quotient of Calcium for CE2 and CE3 sampling points were greater than 1 , which indicated that the borehole water is not safe for drinking due to the risk it poses to human health, however, CE1 sampling location is less than 1, showing that it poses no risk to human life.

\section{CONCLUSION}

Ground water from an unpolluted site is generally safe for domestic usage. Hazard quotient of temperature, dissolved oxygen and calcium except for CE 1 were above 1 while Turbidity, pH, EC, TDS, BOD, Chloride, Sulphate, Magnesium, Phosphate, Total Hardness, Nitrate, $\mathrm{Pb}, \mathrm{Cu}, \mathrm{Fe}$ were all less than 1 . However, $\mathrm{pH}$ in all location is less than 5 meaning the water is acidic. This is an indication that the borehole water is risky for human consumption and can result to adverse health effect.

\section{RECOMMENDATIONS}

The general public especially those living within the vicinity of the study area should be enlightened and educated on their groundwater quality, the health implications of drinking contaminated water and the importance of treating the water before drinking.

Regulatory agency shouldered with the responsibility of monitoring borehole water quality should be proactive and government agencies in charge of approving building plan should ensure WHO recommended safe distance of minimum 30 meters between septic tank and borehole water is followed prior approving the plan and also enforce compliance.

\section{REFERENCES}

[1] M.V. Yates (September, 1985) Septic tank density and ground water contamination. https://doi.org/10.1111/j.17456584.1985.tb01506.

[2] I. Fubara-Mauel and R.P. Jumbo (May, 2014) The effect of septic tank location on borehole water quality in Port-Harcourt. International Journal of Engineering and Technology. 4(5) pp 236-242.

[3] L.W. Canter, and R.C. Knox (1985) Septic tank system effects on ground water quality: Chelsea, Mich., Lewis Publications, Inc., $336 \mathrm{p}$

[4] o. Momot, and b. Synzynys (2005). Toxic aluminum and heavy metals in groundwater of middle Russia: Health risk assessment. International Journal of Environmental Research and Public Health. 2(2): pp 214-218.
[5] B. Wu, Y Zhang, X. Zhang, and S. Cheng (2010). Health risk from exposure of organic pollutants through drinking water consumption in Nanjing, China. Bulletin of Environmental Contamination and Toxicology. 84. pp 46-50.

[6] USEPA. Guidelines for exposure assessment. EPA/600/Z-92/001. US Environmental Protection Agency, Risk Assessment Forum, Washington, DC; 1992.

[7] WHO (World Health Organization). Guidelines for Drinking-water Quality. (4TH ed.). 2011.

[8] B. G. Maddock and D. Taylor. The Acute Toxicity and Bioaccumulation of Some Lead Compounds in Marine Animals. In: Lead in The Marine Environment. Proceeding of The International Experts Discussion on Lead Occurrence, Fate and Pollution In The Marine Environment, Rovinj, Yugoslavia, pp 233-261. 18 - 22 October, 1977.

[9] R. J. Lewis. Hazardous Chemicals Desk Reference (2nd eds), Reinhold: Van Nostrand; 1991.

[10] APHA Standard. 3125b: inductively coupled plasma/mass spectrometry method for trace metals. Washington, DC: American Public Health Association; 2005.

[11] NSDWQ, Nigerian Standard for Drinking Water Quality, NIS: 2015, 554, pp 1-28.

[12] A. Gregoriadou, K. Delidou, and D. Dermosonoglou, heavy metals in drinking water in the Saloniki area Greece. 2001.

[13] S.A Nta, M.J. Ayotamuno, A.H. Igoni, R.N. Okparanma, and S.O. Udo (September, 2020). Application of hazard quotient for the assessment of potential health risk of groundwater users around Uyo main dumpsite. Asian Journal of Advanced Research and Report (UJET), 6(1). pp 49-54.

[14] WHO. World Health Organization, Drinking Water (June, 2019). Retrieved from www. who.int/news-room.

[15] UNEP, United Nations Environmental Protection. UN News (4 August, 2011). Retrieved from https:// news.un.org/en/story.

[16] K. Weggler, M. J. McLaughlin, and R. D. Graham, "Effect of chloride in soil solution on the plant availability of biosolid-borne cadmium," journal of environmental quality, vol. 33, no. 2, pp. 496-504, 2004.

[17] WHO, guidelines for drinking water quality, 3rd edn., WHO, Geneva, 2003. 